\title{
Physicochemical Properties and Solubility of Hydrochloride Mucolytic Agents
}

\author{
Aneta Pobudkowska $^{1}$ (D) Agnieszka Śliwińska ${ }^{1} \cdot$ Kamil Nosol $^{1}$
}

Received: 24 April 2020 / Accepted: 7 December 2020 / Published online: 22 April 2021

(c) The Author(s) 2021

\begin{abstract}
Two widely used active pharmaceutical ingredients (API), ambroxol hydrochloride $(\mathrm{AMB} \cdot \mathrm{HCl})$ and bromhexine hydrochloride $(\mathrm{BMH} \cdot \mathrm{HCl})$, belong to the expectorant and mucokinetic group of drugs. Their applications are found in the treatment of the upper respiratory tract and bronchopulmonary diseases. The compounds have similar chemical structures, but are different enough to distinguish their physicochemical properties. To understand better the bioavailability of the drugs a series of experiments was performed to establish significant parameters. With differential scanning calorimetry (DSC) the temperature and the enthalpy of fusion were determined with no observed polymorphic transformations. The phase diagrams for binary systems \{active agent (1) + solvent (2) \} were determined with three solvents: 1-octanol, water and ethanol, to describe phase equilibria by correlation with the local composition models: Wilson, UNIQUAC and NRTL. Finally, the Bates-Schwarzenbach method was used to establish the ionization constants of $\mathrm{AMB} \cdot \mathrm{HCl}$ and $\mathrm{BMH} \cdot \mathrm{HCl}$ at two temperatures: room temperature $298.2 \mathrm{~K}$ and human body temperature $310.2 \mathrm{~K}$. Our study can give an insight into further drug delivery system design and help to create more effective drug application forms.
\end{abstract}

Keywords Ambroxol hydrochloride $\cdot$ Bromhexine hydrochloride $\cdot$ Solubility $\cdot$ Local composition model $\cdot$ Acid dissociation constant $\cdot$ Thermophysical properties

\section{Introduction}

Many active pharmaceutical ingredients (API) have already been studied, but to develop more efficient, accessible and cheaper drugs, more specific API properties are desired. Moreover, the solubility of every API has a significant impact on the pharmacokinetic and pharmacodynamic properties of the substance [1]. In this research, the active substances, ambroxol hydrochloride (AMB$\cdot \mathrm{HCl}$ ) and bromhexine hydrochloride $(\mathrm{BMH} \cdot \mathrm{HCl})$, widely used in the treatment of upper respiratory and bronchopulmonary diseases, have been described. Both $\mathrm{AMB} \cdot \mathrm{HCl}$ and $\mathrm{BMH} \cdot \mathrm{HCl}$ belong to the group of mucolytic drugs, and

Aneta Pobudkowska

pobudka@ch.pw.edu.pl

1 Department of Physical Chemistry, Faculty of Chemistry, Warsaw University of Technology, Noakowskiego 3, 00-664 Warsaw, Poland 
more precisely are expectorants and muccinetics [2]. Their activities aim to facilitate the transport of bronchial secretion. $\mathrm{BMH} \cdot \mathrm{HCl}$ affects the mucosal rheological properties by limiting the synthesis of glycoproteins that are released to the mucus and change its viscosity [3] as well as causing the depolarization of macromolecules. The reduced amount and density of secretion causing ciliary motion have been confirmed in studies [4], but no direct effect of $\mathrm{BMH} \cdot \mathrm{HCl}$ on cystic epithelials has been demonstrated. $\mathrm{AMB} \cdot \mathrm{HCl}$ is also a secretolytic agent used in the treatment of acute and chronic bronchial pneumonia. This substance contributes to the resumption of the respiratory purification processes and plays an important role in the activation of the body's natural defense mechanism.

These API molecules show similarity in their chemical structures, but the physicochemical properties have been poorly studied. The available literature provides data on approximate values of melting temperatures $[5,6]$; however, the majority of available properties, including water and alcohol solubilities remain only as predicted parameters. The aim of this work is to determine and compare the basic physicochemical properties of $\mathrm{AMB} \cdot \mathrm{HCl}$ and $\mathrm{BMH} \cdot \mathrm{HCl}$. The understanding of how particular moieties affect the properties of the API is a key in designing new API molecules. Therefore, we provide data on: (1) thermal analysis of the substances, using differential scanning calorimetry (DSC) and thus determining the basic thermal effects of the pure substances; (2) determination of solubility by measuring the dissolution temperatures over a wide range of temperatures using dynamic and spectrophotometric methods; (3) correlation of the solubility measurement points using equations based on the theory of local concentration, and (4) determination of acidity constants at $298.2 \mathrm{~K}$ and $310.2 \mathrm{~K}$.

The parameters determined are valuable information about the examined substances. The conducted research may be helpful in determining the thermal stability of the examined substances, optimal solubility necessary to determine the method of administration of the substance and the dose at which it should be administered as well as membrane permeability.

\section{Experimental}

\subsection{Materials}

Studied APIs were purchased from Sigma-Aldrich, i.e. AMB·HCl (CAS Number 2382892-4) and $\mathrm{BMH} \cdot \mathrm{HCl}$ (CAS Number 611-75-6). Both substances were crystalline powders with more than $98 \%$ purity, wherefore no additional purification was done. Their chemical structures are presented in the Fig. 1. AMB $\cdot \mathrm{HCl}$ is a derivative of $\mathrm{BMH} \cdot \mathrm{HCl}$, which differs from it by the hydroxyl group in the trans- 4 position of the cyclohexyl ring and by the absence of the methyl group in the amine group. In Table 1 the information about the APIs and solvents, i.e. water, ethanol and 1-octanol, are presented. The solvents other than water were kept under activated molecular sieves to protect them from water absorption. The solvents was prepared by double distillation, degassing, deionization and filtration with Milipore Elix 3. Solutions were prepared from substances purchased from POCH S.A.: potassium dihydrogen phosphate (CAS No. 7778-77-0; 0.995 mass fraction purity); disodium hydrogen phosphate (CAS No. 7558-79-4; 0.98 mass fraction purity); borax (CAS No. 1303-96-4; 0.995 mass fraction purity); sodium chloride (CAS No. 7647-14-5; 0.998 mass fraction purity); hydrochloric acid (CAS No. 7647-01-0; > 0.35 mass fraction purity) and 
Fig. 1 Structural formulae of investigated APIs: a AMB·HCl, b $\mathrm{BMH} \cdot \mathrm{HCl}$<smiles>Nc1c(Br)cc(Br)cc1CNC1CCC(O)CC1</smiles>

(b)<smiles>CN(Cc1cc(Br)cc(Br)c1N)C1CCCCC1</smiles>

sodium hydroxide (CAS No. 1310-73-2; 0.988 mass fraction purity). All solutions were filtrated twice with a Schott funnel having $4 \mu \mathrm{m}$ diameter pores.

\subsection{Differential Scanning Calorimetry, DSC}

Thermal analysis of the examined substances was carried out using differential scanning calorimetry (DSC). The measured parameters are: temperature of fusion $\left(T_{\text {fus, } 1}\right)$ and enthalpy of fusion $\left(\Delta_{\text {fus }} H_{1}\right)$. The experiments were performed with the DSC 1 STAR System (Mettler Toledo) calorimeter equipped with liquid nitrogen cooling system and operating in a heat-flux mode. Calibration of the apparatus was performed on a 0.999999 mol fraction purity indium sample. The uncertainty of the melting temperature was $\pm 0.1 \mathrm{~K}$ and the enthalpy of fusion $\pm 0.1 \mathrm{~kJ} \cdot \mathrm{mol}^{-1}$. The samples were held in ambient air in hermetic aluminium pans weighing about $50 \mathrm{mg}$ and the reference sample was an empty hermetic aluminium pan. Masses of the examined samples were about $10 \mathrm{mg}$. The analysis was performed in the temperature range from 173 to $543 \mathrm{~K}(\mathrm{AMB} \cdot \mathrm{HCl}$ ) and from 173 to $557 \mathrm{~K}$ $(\mathrm{BMH} \cdot \mathrm{HCl})$. The measuring chamber was heated at a rate of $10 \mathrm{~K} \cdot \mathrm{min}^{-1}$. The thermophysical characteristics were registered by STAR software. The molar volume of substances and solvents were calculated using the Barton's group contribution method [7]. The results of this study are listed in Table 2 and in Fig. 1S (Supplementary Material).

\subsection{Solubility Measurements}

The research contains six binary systems: \{substance (1) + solvent (2) \}. Two measuring methods were used: dynamic-visual and saturation shake flask with UV-Vis spectroscopy. The dynamic-visual method was performed by preparing mixtures of solute and solvent by weighting pure components to within $1 \times 10^{-4} \mathrm{~g}$ in a Pyrex glass cell with a mixing 


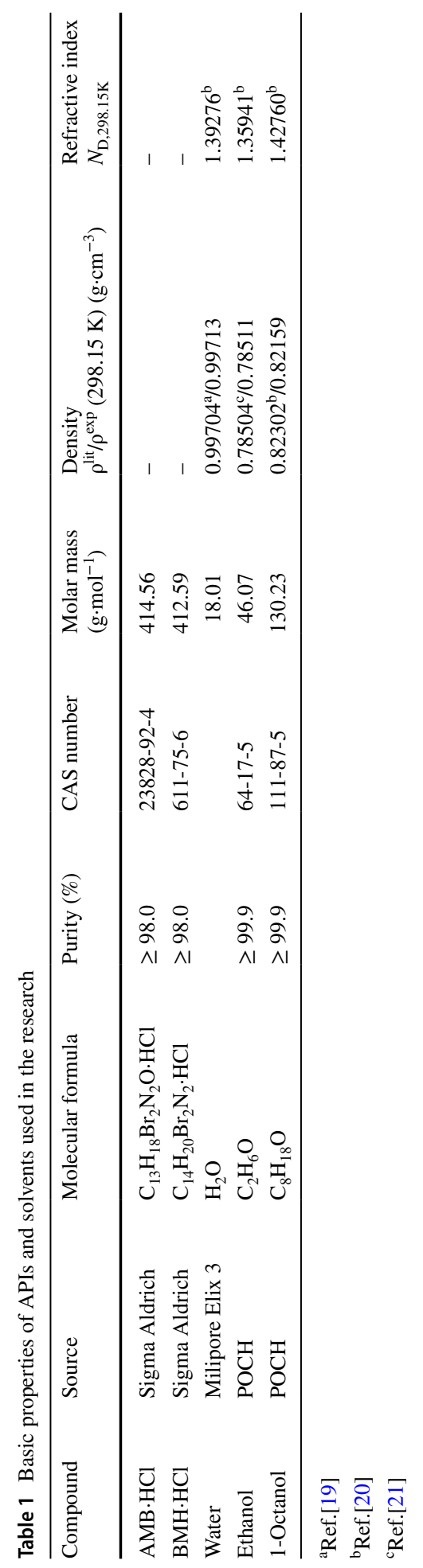


Table 2 Thermophysical properties of APIs obtained by DSC measurements: temperature $\left(T_{\text {fus, } 1}\right)$ and enthalpy $\left(\Delta_{\text {fus }} H_{1}\right)$ of fusion, heat capacity $\left(\Delta C_{p(\text { fus }), 1}\right)$ at the temperature of fusion and molar volume $\left(V_{\mathrm{m}}^{298.15}\right)$

\begin{tabular}{llllc}
\hline Name of API & $T_{\text {fus }, 1}{ }^{\mathrm{a}}(\mathrm{K})$ & $\Delta_{\text {fus }} H_{1}{ }^{\mathrm{b}}\left(\mathrm{kJ} \cdot \mathrm{mol}^{-1}\right)$ & $\begin{array}{l}\Delta C_{p(\text { fus }) 1}{ }^{\mathrm{c}} \\
\left(\mathrm{J} \cdot \mathrm{mol}^{-1} \cdot \mathrm{K}^{-1}\right)\end{array}$ & $\begin{array}{l}V_{\mathrm{m}}^{298.15 \mathrm{~d}} \\
\left(\mathrm{~cm}^{3} \cdot \mathrm{mol}^{-1}\right)\end{array}$ \\
\hline $\mathrm{AMB} \cdot \mathrm{HCl}$ & 514.38 & 42.43 & 82.50 & 275.6 \\
$\mathrm{BMH} \cdot \mathrm{HCl}$ & 519.99 & 44.11 & 84.83 & 285.2
\end{tabular}

No solid-solid phase transition was observed

${ }^{\text {a }}$ Standard uncertainty $\mathrm{u}\left(T_{\text {fus, }, 1}\right)=0.1 \mathrm{~K}$

${ }^{\mathrm{b}}$ Standard uncertainty $\mathrm{u}\left(\Delta_{\text {fus }} H_{1}\right)=0.1 \mathrm{~kJ} \cdot \mathrm{mol}^{-1}$

${ }^{\mathrm{c}}$ Calculated with $T_{\text {fus }, 1}$ and $\Delta_{\text {fus }} H_{1}$

${ }^{\mathrm{d}}$ Calculated according to the Barton's group contribution method[7]

element. Examined systems were placed in the thermostated water bath and heated slowly $\left(5 \mathrm{~K} \cdot \mathrm{min}^{-1}\right)$ with continuous stirring until the disappearance of the last crystal. The temperature of disappearance of the last crystal was visually observed and registered as the temperature of the liquidus curve. All mixtures were prepared by the mass and represented as a mole fraction; the temperatures were measured with electronic thermometer P 550 (DOSTMANN electronic $\mathrm{GmbH}$ ) calibrated on the basis of ITS-90. Saturation temperatures of the mixtures were determined from $293.2 \mathrm{~K}$ to the boiling point of the solvent. To determine solubility of sparingly soluble binary systems (mole fraction of examined substances less than $10^{-5}$ ) the applicable method was the shake-flask method with UV-Vis spectroscopy (Perkin-Elmer Life and Analytical Sciences Lambda 35, Shelton USA). For this purpose, solutions of substances with low solubility were prepared and placed in vessels at a controlled temperature. These vessels with a mixing element were placed on a magnetic stirrer. The temperature was set and the mixing was switched on for $24 \mathrm{~h}$, and then the mixing was switched off for $24 \mathrm{~h}$ to establish equilibrium in the solution. After that time, the liquid phase was taken and 2-propanol as co-solvent was added in the ratio 1:6. The first measurement was made at $298.2 \mathrm{~K}$, the next measurements were made at increasingly higher temperatures, changing by $5 \mathrm{~K}$, up to $323.2 \mathrm{~K}$. The spectra were recorded in the wavelength range from 190 to $340 \mathrm{~nm}$. Each experiment was performed at least in duplicate.

Experimental points have been described by thermodynamic equations based on the theory of local concentrations: Wilson, NRTL, UNIQUAC [8-10]. The experimental data are presented in Table 1S, Table 3 and in Figs. 2 and 3.

\section{$2.4 \mathrm{p} K_{\mathrm{a}}$ Determination}

The $\mathrm{p} K_{\mathrm{a}}$ values were measured by the spectrophotometric Bates-Schwarzenbach method using an UV-Vis spectrophotometer (Perkin-Elmer Life and Analytical Sciences Lambda 35, Shelton USA). For each substance three solutions were prepared: in $0.2 \mathrm{~mol} \cdot \mathrm{dm}^{-3}$ hydrochloric acid, in $0.2 \mathrm{~mol} \cdot \mathrm{dm}^{-3}$ sodium hydroxide and in a buffer solution $(\mathrm{pH}=7.2$ and $\mathrm{pH}=9.2$ ). Aqueous acid, base and buffer solutions were used as references. Measurements were carried out at two temperatures $298.2 \mathrm{~K}$ and 310.2 K. Samples were scanned with a scan step of $1 \mathrm{~nm}$ from 340 to $190 \mathrm{~nm}$. Values of the $\mathrm{p} K_{\mathrm{a}}$ have been calculated by following equation: 
Table 3 The correlation parameters of experimental solubility results for binary systems $\{$ API $(1)+$ sol$\operatorname{vent}(2)\}$ by means of the Wilson. UNIQUAC and NRTL equations

\begin{tabular}{|c|c|c|c|c|c|c|c|}
\hline \multirow[t]{3}{*}{ API } & \multirow[t]{3}{*}{ Solvent } & \multicolumn{3}{|l|}{ Parameters } & \multicolumn{3}{|c|}{$\begin{array}{l}\text { Root-mean-square } \\
\text { deviations }\end{array}$} \\
\hline & & Wilson (W) & NRTL (N) & UNIQUAC (U) & W & $\mathrm{N}$ & $\mathrm{U}$ \\
\hline & & $\begin{array}{l}g_{12}-g_{11} \\
g_{12}-g_{22}\left(\mathrm{~J} \cdot \mathrm{mol}^{-1}\right)\end{array}$ & $\begin{array}{l}g_{12} \\
g_{21}\left(\mathrm{~J} \cdot \mathrm{mol}^{-1}\right)\end{array}$ & $\begin{array}{l}u_{12} \\
u_{21}\left(\mathrm{~J} \cdot \mathrm{mol}^{-1}\right)\end{array}$ & $\sigma_{T}(\mathrm{~K})$ & $\sigma_{T}(\mathrm{~K})$ & $\sigma_{T}(\mathrm{~K})$ \\
\hline \multirow[t]{4}{*}{$\mathrm{AMB} \cdot \mathrm{HCl}$} & Water & -5653.06 & 15240.23 & 91704.11 & 1.59 & $4.23^{\mathrm{a}}$ & 9.20 \\
\hline & & 18369.51 & 2252.77 & 1695.13 & & & \\
\hline & Ethanol & -3319.99 & 21139.36 & 10150.67 & 2.73 & $3.17^{\mathrm{b}}$ & 1.08 \\
\hline & & 94171.85 & 545.96 & -1313.83 & & & \\
\hline \multirow[t]{6}{*}{$\mathrm{BMH} \cdot \mathrm{HCl}$} & Water & -1193.90 & 17649.43 & 136972.27 & 0.85 & $2.26^{\mathrm{c}}$ & 5.54 \\
\hline & & 17694.86 & 6315.13 & 2307.31 & & & \\
\hline & Ethanol & -3071.98 & 17754.21 & 6139.93 & 0.44 & $1.25^{\mathrm{c}}$ & 0.43 \\
\hline & & 19237.14 & 1401.48 & -1052.29 & & & \\
\hline & 1-Octanol & 945.71 & 21572.51 & 6153.30 & 4.68 & $3.92^{\mathrm{b}}$ & 1.30 \\
\hline & & 79330.58 & 2284.50 & -1580.38 & & & \\
\hline
\end{tabular}

${ }^{\mathrm{a}} \alpha=0.35$

${ }^{\mathrm{b}} \alpha=0.25$

${ }^{\mathrm{c}} \alpha=0.30$

$$
\mathrm{p} K_{\mathrm{a}}=\mathrm{p}\left(a_{\mathrm{H}} \gamma_{\mathrm{Cl}}\right)-\log _{10}\left(\frac{D_{\mathrm{HA}}-D}{D-D_{\mathrm{A}^{-}}}\right)
$$

where $\mathrm{p} K_{\mathrm{a}}$ is an ionization constant, $\mathrm{p}\left(a_{\mathrm{H}} \gamma_{\mathrm{Cl}}\right)$ is an acidity function, $D_{\mathrm{HA}}, D_{\mathrm{A}-}, D$ are absorbance values in acid, base and buffer solutions, respectively [11]. The experimental data are presented in Tables 4 and 5 and in Figs. 4 and 5.

\section{Modelling}

The melting temperatures of the phase diagrams in binary systems \{solid (1) + liquid (2) \} are represented using thermodynamic models based on local concentration theory. They were used to determine deviations from ideal solubility in comparison with the experimentally determined points. The equations used are presented in published papers $[9,10]$. The local concentration theory based models were chosen due to its applicability to a wide variety of APIs. The models have been used to determine the solubility of $e$.g. flurbiprofen [8], octopamine $\mathrm{HCl}$ [9], synephrine [10], lobeline $\mathrm{HCl}$ [12], methyl xanthines [13], protein kinase CK2 inhibitors [14] or derivatives of anthranilic acid [15].

According to local concentration theory, the average concentrations of the substances described at the molecular level are differentiated. Local compositions of liquid solutions in the vicinity of the different molecules are different and depend on the relative magnitude of forces of interaction between the molecules. This theory is applied in the description of the liquid mixtures. Based on this theory, mathematical equations were derived: Wilson's equation [16], the NRTL equation [17] and the UNIQUAC equation [18] which were used to 


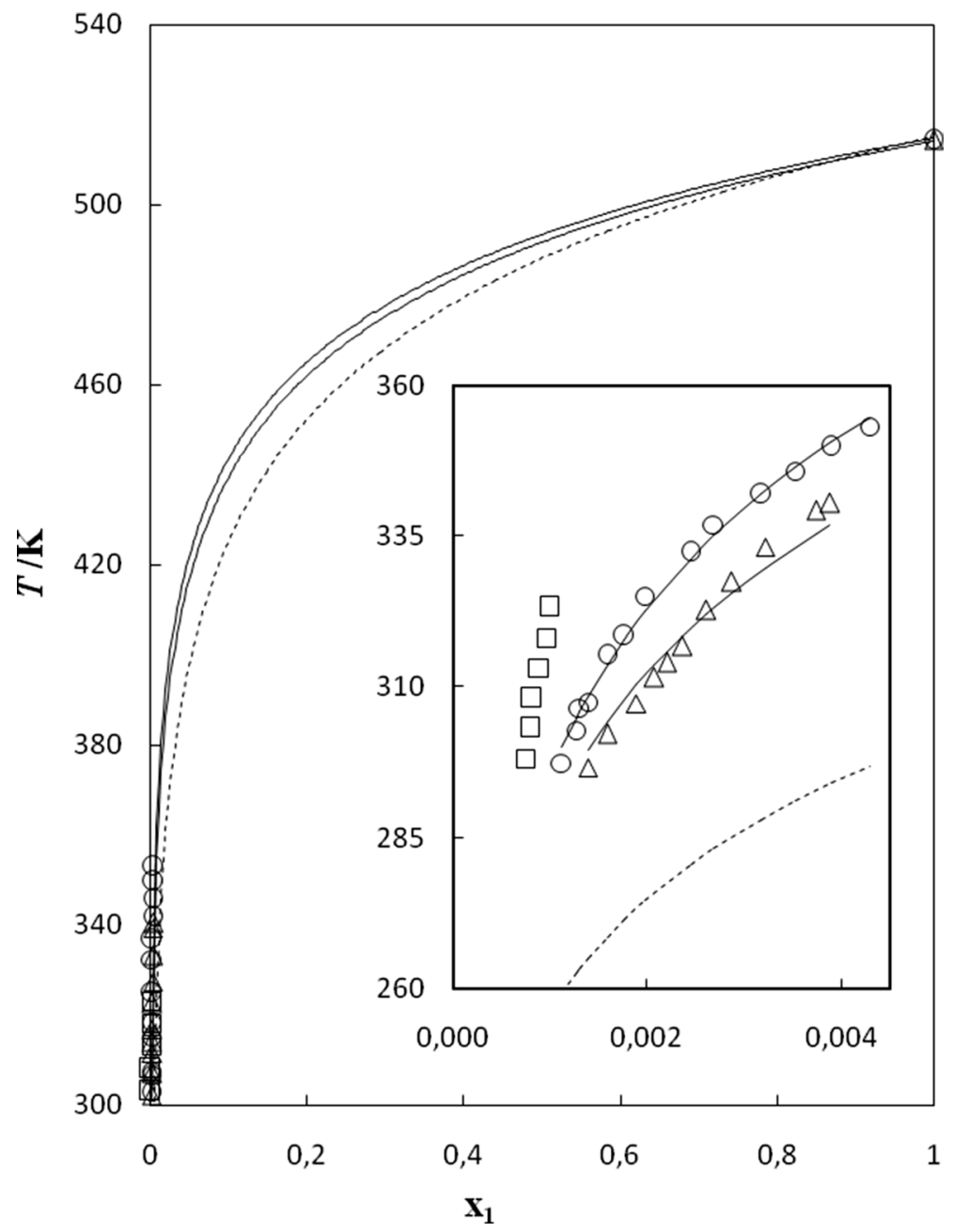

Fig. 2 The experimental and calculated solubility equilibria for binary systems $\{\mathrm{AMB} \cdot \mathrm{HCl}(1)+$ solvent (2)\}: (open circle) water; (open triangle) ethanol and (open square) 1-octanol. Solid lines (-) correspond to the Wilson equation for water and the UNIQUAC equation for ethanol. Dotted line (- - -) corresponds to ideal solubility

calculate the ideal solubility on the basis of measurement points. Wilson's equation can be used to describe liquid solutions with total dilatability with large deviations from the ideal state. The NRTL equation is used for solutions with large deviations from ideality and especially for solutions with limited miscibility, including liquid-liquid balance. The UNIQUAC equation is used to describe liquid-steam and liquid-liquid equilibria. It is used for any solutions with small and large molecules including polymers. 


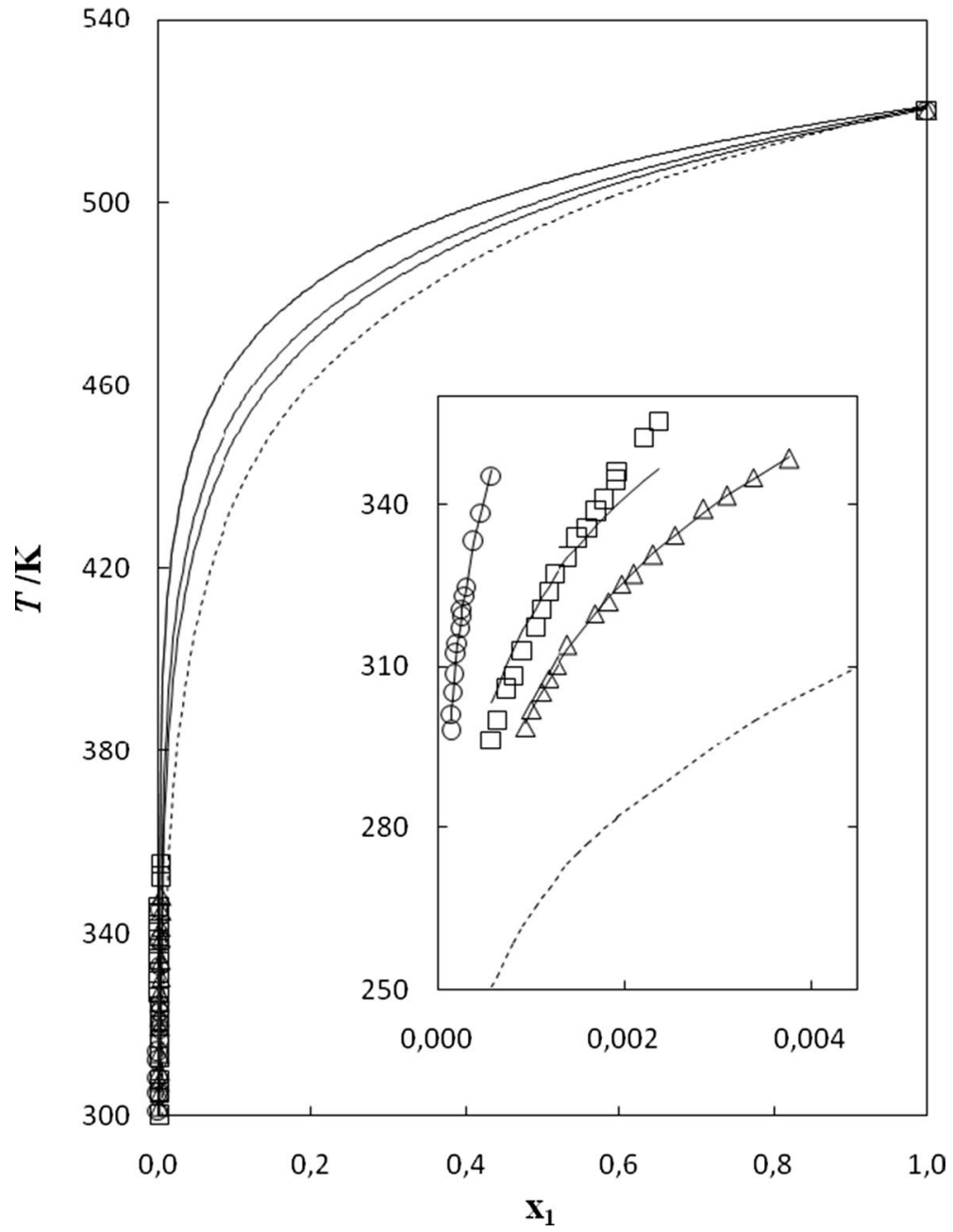

Fig. 3 The experimental and calculated solubility equilibria for binary systems $\{\mathrm{BMH} \cdot \mathrm{HCl}(1)+$ solvent (2)\}: (open circle) water; (open triangle) ethanol and (open square) 1-octanol. Solid lines (-) correspond to the Wilson equation for water and the UNIQUAC equation for ethanol and 1-octanol. Dotted line (- - -) corresponds to ideal solubility.

Table 4 Values of an acidity functions $p\left(a_{\mathrm{H}} \gamma_{\mathrm{Cl}}\right)$ and ionic strength (I) for buffers [11]

\begin{tabular}{lllll}
\hline $\begin{array}{l}\text { Buffer } \\
\mathrm{pH}\end{array}$ & Composition (mole concentration) & $T(\mathrm{~K})$ & $p\left(a_{\mathrm{H}} \gamma_{\mathrm{Cl}}\right)$ & $I$ \\
\hline 7.2 & Potassium dihydrogen phosphate (0.01000) & 298.2 & 7.040 & 0.04 \\
& Disodium hydrogen phosphate (0.01000) & 310.2 & 7.022 & \\
9.2 & Borax (0.01038) & 298.2 & 9.239 & 0.04 \\
& Sodium chloride (0.01925) & 310.2 & 9.149 & \\
\hline
\end{tabular}


Table 5 The experimental values of active pharmaceutical ingredient $\mathrm{p} K_{\mathrm{a}}(p=101 \mathrm{kPa})$

\begin{tabular}{llll}
\hline Name of API & $T(\mathrm{~K})$ & $\mathrm{p} K_{\mathrm{a}}^{\exp }$ & $\begin{array}{l}\text { Buffer } \\
\mathrm{pH}\end{array}$ \\
\hline $\mathrm{AMB} \cdot \mathrm{HCl}$ & 298.2 & $6.87 \pm 0.12$ & 7.2 \\
& 310.2 & $6.73 \pm 0.09$ & 7.2 \\
$\mathrm{BMH} \cdot \mathrm{HCl}$ & 298.2 & $8.87 \pm 0.03$ & 9.2 \\
& 310.2 & $9.05 \pm 0.24$ & 9.2 \\
\hline
\end{tabular}

The values of ionization constant for both APIs were not reported in the literature

\section{Results and Discussion}

The aim of this research is to determine basic physicochemical properties of chosen two hydrochloride mucolytic agents such as: thermal stability, solubility and ionization constant.

The main core structure of the studied substances is based on 2,4-dibromo-6[(cyclohexylamino)methyl]aniline and modified with substituents differing in polarity (AMB·HCl-hydroxyl group substituent; $\mathrm{BMH} \cdot \mathrm{HCl}-$ methyl group substituent). Computed values of physicochemical properties are presented in Table 6.

Thermal analysis was performed by differential scanning calorimetry. This method was chosen to determine the pure API's fusion temperature, fusion enthalpy, temperature of phase transition and enthalpy of phase transition, and also to determine whether polymorphism occurs. The registered values were heat flow $\left(\mathrm{W} \cdot \mathrm{g}^{-1}\right)$ and temperature $(\mathrm{K})$. Thermal analyses were performed in the temperature range from 173 to $543 \mathrm{~K}(\mathrm{AMB} \cdot \mathrm{HCl})$ and from 173 to $557 \mathrm{~K}(\mathrm{BMH} \cdot \mathrm{HCl})$. Up to $440 \mathrm{~K}$ AMB$\cdot \mathrm{HCl}$ did not exhibit phase transitions, however, above this temperature the melting process of the substance was initiated. The melting point temperature is $T_{\text {fus, } 1}=514.38 \mathrm{~K}$. The experimentally determined melting point differs from the literature value by $7-8 \mathrm{~K}$ (Table 6 ). The surface of melting process signal corresponds to the enthalpy of melting and is $\Delta_{\text {fus }} H_{1}=42.43 \mathrm{~kJ} \cdot \mathrm{mol}^{-1}$. These parameters for $\mathrm{BMH} \cdot \mathrm{HCl}$ are $T_{\text {fus }, 1}=519.99 \mathrm{~K}$ and $\Delta_{\text {fus }} H_{1}=44.11 \mathrm{~kJ} \cdot \mathrm{mol}^{-1}$. This melting temperature is 3-7 K higher than the literature value. The temperatures are high for organic compounds but also enthalpies of fusion are low because of narrow signals corresponding to the melting process. AMB $\cdot \mathrm{HCl}$ showed lower values of the experimentally determined $T_{\text {fus, } 1}$ and $\Delta_{\text {fus }} H_{1}$ than $\mathrm{BMH} \cdot \mathrm{HCl}$. On the basis of these parameters, the heat capacities $\left(\Delta C_{p(\mathrm{fus}), 1}\right)$ of the substances were calculated. These values slightly differed (for AMB $\mathrm{HCl} \Delta C_{p \text { (fus), } 1}$ $=82.50 \mathrm{~J} \cdot \mathrm{mol}^{-1} \cdot \mathrm{K}^{-1}$; for $\mathrm{BMH} \cdot \mathrm{HCl} \Delta C_{p(\mathrm{fus}), 1}=84.83 \mathrm{~J} \cdot \mathrm{mol}^{-1} \cdot \mathrm{K}^{-1}$ ) due to the small differences in the structure of the substances. Whereas the molar volumes calculated using Barton's group share methods [7] in normal conditions differed by about $10 \mathrm{~cm}^{3} \cdot \mathrm{mol}^{-1}$ as a result of the higher value of the molar volume of the methyl group (bromhexine hydrochloride) than the hydroxyl group (ambroxol hydrochloride). $\mathrm{AMB} \cdot \mathrm{HCl}$ and $\mathrm{BMH} \cdot \mathrm{HCl}$ are thermally stable substances in a wide temperature range from 173 to $440 \mathrm{~K}$, with no phase transitions. This affects the convenience of the storage and the usage of examined substances. We concluded that neither hydroxyl group nor methyl group destabilizes the compound. The results of this study are presented in Table 2 and in Fig. 1S.

Another property tested and compared was the solubility. It was determined in three solvents: water, ethanol and 1-octanol. Six liquid-solid systems in two-component systems were tested: $\{$ drug $(1)+$ solvent $(2)\}$. Five of these were determined by the shakeflask method and one by the spectrophotometric method $\{\mathrm{AMB} \cdot \mathrm{HCl}(1)+1$-octanol (2) $\}$. 

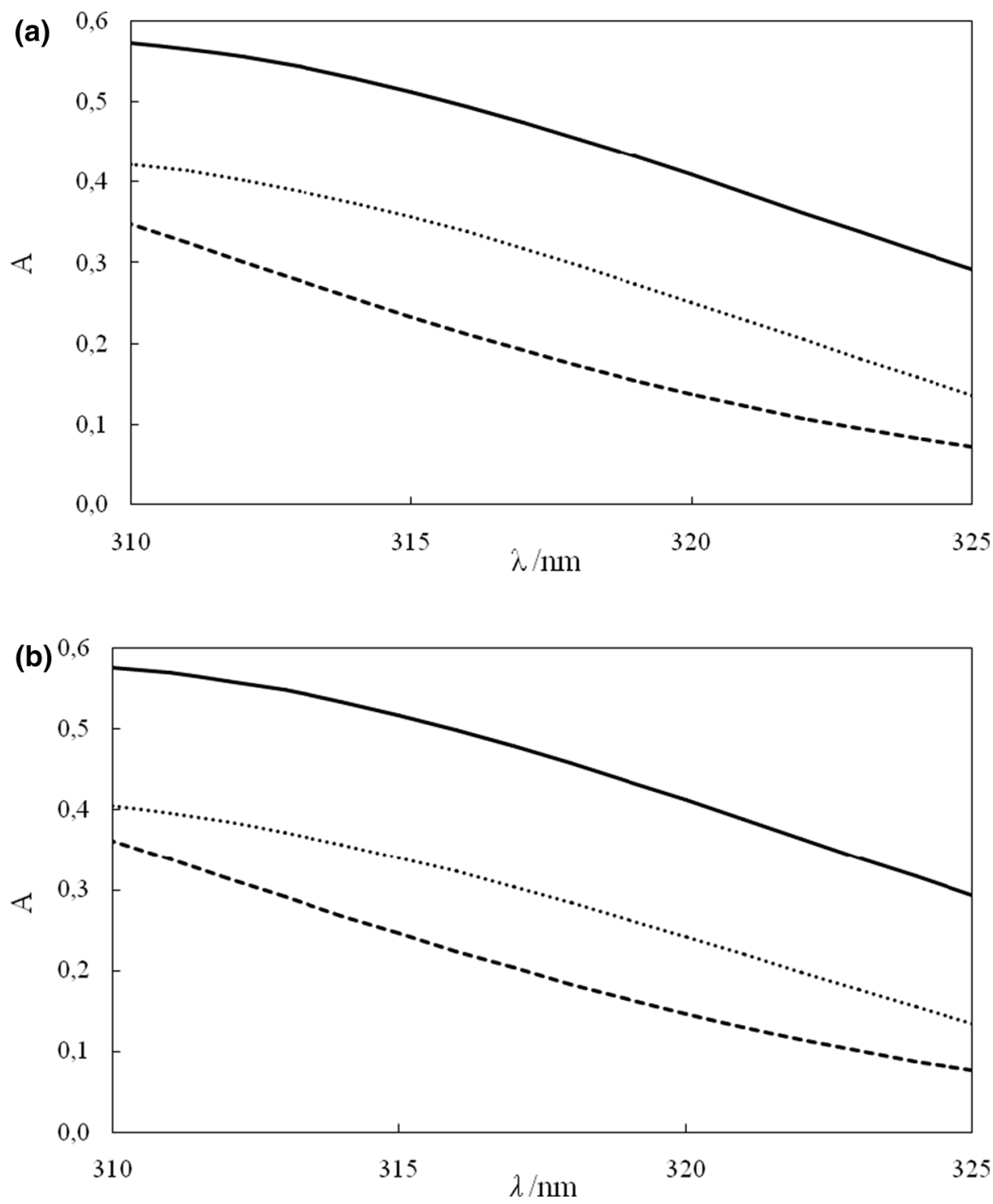

Fig. 4 The UV-Vis spectra at a $T=298.2 \mathrm{~K}$, b $T=310.2 \mathrm{~K}$ for ionization constant measurement-experimental line $\{\mathrm{AMB} \cdot \mathrm{HCl}+$ solvent $\}$. where the solvent corresponds to: $(\cdots .$.$) buffer; (-) 0.2 \mathrm{~mol} \cdot \mathrm{dm}^{-3}$ $\mathrm{HCl} ;(-\ldots) 0.2 \mathrm{~mol} \cdot \mathrm{dm}^{-3} \mathrm{NaOH}$

Experimental points of dissolution temperature for both substances were observed in the range of molar fractions $10^{-4}$ to $10^{-3}$ and were correlated with thermodynamic equations based on the local concentration theory. The equations with the lowest root-mean-square deviations have been selected for systems correlation. Then the obtained solubilities were compared. AMB $\cdot \mathrm{HCl}$ shows the highest solubility in water and lower in the alcohols (ethanol and 1-octanol). The reverse was exhibited by $\mathrm{BMH} \cdot \mathrm{HCl}$. $\mathrm{BMH} \cdot \mathrm{HCl}$ shows the highest solubility in ethanol and lower in 1-octanol and water. The solubility of both compounds 

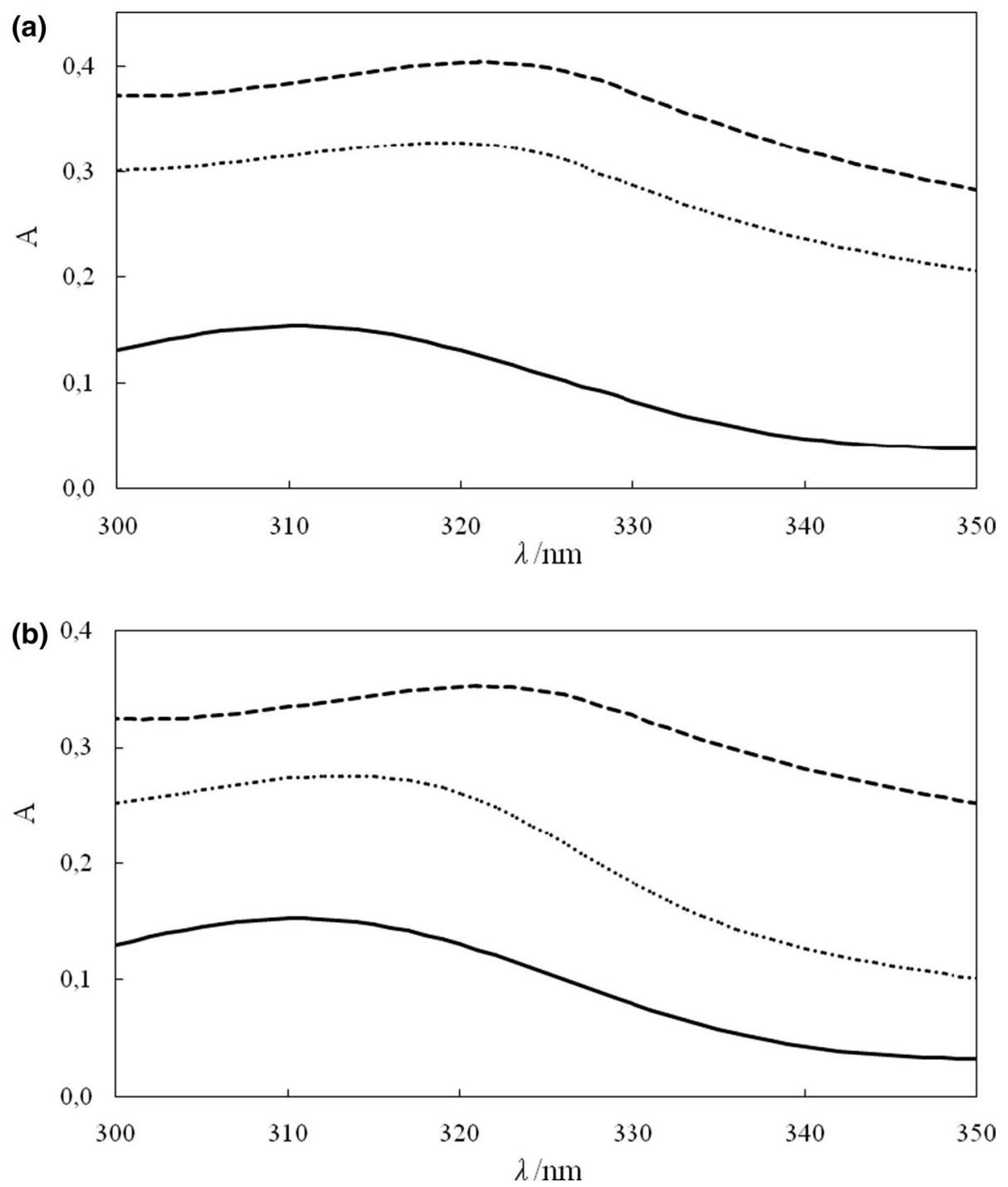

Fig. 5 The UV-Vis spectra at a $T=298.2 \mathrm{~K}, \mathbf{b} T=310.2 \mathrm{~K}$ for ionization constant measurement-experimental line $\{\mathrm{BMH} \cdot \mathrm{HCl}+$ solvent $\}$. where the solvent corresponds to: $(\cdots \cdots)$ buffer; $(-) 0.2 \mathrm{~mol} \cdot \mathrm{dm}^{-3}$ $\mathrm{HCl}$; (- - - ) $0.2 \mathrm{~mol} \cdot \mathrm{dm}^{-3} \mathrm{NaOH}$

show positive deviations from the ideal solubility, which indicates lower solubility than the ideal one. The experimental data were correlated by Wilson's equation. This equation most accurately described the obtained phase equilibria and showed the lowest root-mean-square deviation. The data received are summarized in Table 1S, Table 3 and in Figs. 2 and 3.

Another important parameter characterizing pharmaceutical substances and their application value is the ionization constant. Most drugs can be classified as weak acids or weak bases. Any compound having acidic character may be in the form of an acid or conjugate base; likewise any compound having alkaline character may be in the form of base or 
Table 6 The computed and measured values of physicochemical values for $\mathrm{AMB} \cdot \mathrm{HCl}$ and $\mathrm{BMH} \cdot \mathrm{HCl}$

\begin{tabular}{lll}
\hline Properties & $\mathrm{AMB} \cdot \mathrm{HCl}$ & $\mathrm{BMH} \cdot \mathrm{HCl}$ \\
\hline Measured melting point & $506-507.5 \mathrm{~K}^{\mathrm{a}}$ & $513-517 \mathrm{~K}^{\mathrm{b}}$ \\
Computed water solubility & $0.0185 \mathrm{mg} \cdot \mathrm{mL}^{-1 \mathrm{c}}$ & $0.00362 \mathrm{mg} \cdot \mathrm{mL}^{-1 \mathrm{~d}}$ \\
Computed $\log _{10} P$ & $3.72^{\mathrm{c}}$ & $4.08^{\mathrm{d}}$ \\
& $2.65^{\mathrm{c}}$ & $4.42^{\mathrm{d}}$ \\
Computed $\log _{10} S$ & $-4.3^{\mathrm{c}}$ & $-5^{\mathrm{d}}$ \\
Computed $\mathrm{p} K_{\mathrm{a}}$ acidic & $15.26^{\mathrm{c}}$ & $19.89^{\mathrm{d}}$ \\
Computed $\mathrm{p} K_{\mathrm{a}}$ basic & $9.01^{\mathrm{c}}$ & $9.03^{\mathrm{d}}$ \\
\hline
\end{tabular}

${ }^{\mathrm{a}}$ Ref. [22]

${ }^{\mathrm{b}}$ Ref. [23]

${ }^{\mathrm{c}}$ Ref. [24]

${ }^{\mathrm{d}}$ Ref. [25]

conjugate acid. The drug, after its administration to the patient's body, is given in a specific form, and its acid-base balance largely determines the distribution of the drug in the body. Acidic compounds are most likely to be absorbed in acidic environments and alkaline compounds in alkaline environments. If the drug has a lower $\mathrm{p} K_{\mathrm{a}}$ value, at the physiological $\mathrm{pH}$ value it is more non-ionized, i.e. it tranlocates through the lipid membranes better and thus is able to act faster. Spectrophotometric determinations of $\mathrm{p} K_{\mathrm{a}}$ were performed using the Bates-Schwarzenbach method, at two temperatures, $298.2 \mathrm{~K}$ and $310.2 \mathrm{~K}$. The spectra were recorded in the wavelength range from 340 to $190 \mathrm{~nm}$. For each substance three solutions were prepared: in $0.2 \mathrm{~mol} \cdot \mathrm{dm}^{-3}$ hydrochloric acid, $0.2 \mathrm{~mol} \cdot \mathrm{dm}^{-3}$ sodium hydroxide and in a buffer solution $(\mathrm{pH}=7.2$ and $\mathrm{pH}=9.2)$. Aqueous acid, base and buffer solutions were used as references. The $\mathrm{p} K_{\mathrm{a}}$ values for $\mathrm{AMB} \cdot \mathrm{HCl}$ are $6.87(298.2 \mathrm{~K})$ and $6.73 \mathrm{~K}(310.2 \mathrm{~K})$ and for $\mathrm{BMH} \cdot \mathrm{HCl}$ are $8.87(298.2 \mathrm{~K})$ and $9.05(310.2 \mathrm{~K})$. The ionization constant value for $\mathrm{BMH} \cdot \mathrm{HCl}$ is lower at $298.2 \mathrm{~K}$ than at $310.2 \mathrm{~K}$ and conversely for $\mathrm{AMB} \cdot \mathrm{HCl}$. The $\mathrm{p} K_{\mathrm{a}}$ value in $310.2 \mathrm{~K}$ for $\mathrm{BMH} \cdot \mathrm{HCl}$ is close to that computed for basic $\mathrm{p} K_{\mathrm{a}}$ and for $\mathrm{AMB} \cdot \mathrm{HCl}$, the $\mathrm{p} K_{\mathrm{a}}$ values for both temperatures differ significantly from those determined experimentally (Table 6). AMB $\cdot \mathrm{HCl}$ and $\mathrm{BMH} \cdot \mathrm{HCl}$ are slightly dissociated. They mostly occur in aqueous solutions in their non-ionized forms. Both substances at 298.2 K will exhibit higher membrane permeability than interactions with receptors and at $310.2 \mathrm{~K} \mathrm{BMH} \cdot \mathrm{HCl}$ will have lower membrane interactions compared to AMB $\cdot \mathrm{HCl}$. The data are presented in Tables 4 and 5 and in Figs. 4 and 5.

Summarizing the information obtained through the experiment, it can be concluded that the substances are thermally stable over a wide temperature range, have high melting points, show no other phase transitions (including polymorphism) and no decomposition occurs at the measured temperatures. Furthermore, due to the difference in the structure of $\mathrm{AMB} \cdot \mathrm{HCl}$ and $\mathrm{BMH} \cdot \mathrm{HCl}$ and thus also in polarity, they have a different tendency to dissolve in water and alcohols. AMB $\cdot \mathrm{HCl}$ shows the highest solubility in water and $\mathrm{BMH} \cdot \mathrm{HCl}$ in alcohols. In addition, both substances are slightly dissociated and in aqueous solutions the neutral form dominates. The results correspond to the chemical structures of the APIs. Both contain the 2-amino-3,5-dibromobenzyl core that shows affinity to ethanol molecules explaining the observed solubility in ethanol. The biggest structural difference is defined by the presence of the hydroxyl moiety and protonated amine group in $\mathrm{AMB} \cdot \mathrm{HCl}$ indicating higher hydrophilicity of the molecule in comparison to $\mathrm{BMH} \cdot \mathrm{HCl}$. This agrees with 
our results that show $\mathrm{BMH} \cdot \mathrm{HCl}$ of the lowest solubility in water and $\mathrm{AMB} \cdot \mathrm{HCl}$ of the highest solubility in water.

\section{Conclusions}

The differential scanning microcalorimetry shows the basic thermophysical values for the APIs such as the melting point $\left(T_{\text {fus, } 1}\right)$ and the melting enthalpy $\left(\Delta_{\text {fus }} H_{1}\right)$. AMB·HCl and $\mathrm{BMH} \cdot \mathrm{HCl}$ were examined in the range of temperatures between 173 and $556 \mathrm{~K}$. From 173 to $500 \mathrm{~K}$ the substances show no phase transitions. Above $500 \mathrm{~K}$ there are changes in heat flow related to the start of the melting process of examined substances. AMB $\cdot \mathrm{HCl}$ as well as $\mathrm{BMH} \cdot \mathrm{HCl}$ have high melting point temperatures $\left(\mathrm{AMB} \cdot \mathrm{HCl}, T_{\text {fus }, 1}=514.38 \mathrm{~K}\right.$; $\left.\mathrm{BMH} \cdot \mathrm{HCl}, T_{\text {fus }, 1}=519.99 \mathrm{~K}\right)$. The enthalpies of fusion are $42.43 \mathrm{~kJ} \cdot \mathrm{mol}^{-1}$ for AMB $\cdot \mathrm{HCl}$ and $44.11 \mathrm{~kJ} \cdot \mathrm{mol}^{-1}$ for $\mathrm{BMH} \cdot \mathrm{HCl}$. The values of melting point temperatures as well as enthalpies of fusion are approximate due to similarity in the structures. Examined substances have no phase transitions in the temperature range from 173 to $543 \mathrm{~K}(\mathrm{AMB} \cdot \mathrm{HCl})$ and from 173 to $557 \mathrm{~K}(\mathrm{BMH} \cdot \mathrm{HCl})$. Results given by thermal analysis research $\left(\Delta_{\text {fus }} H_{1}\right.$, $T_{\text {fus, } 1}$ ) are necessary to determine the thermal effects within the pure substances and to compute the activity coefficients that characterise deviations from ideal solubility compared to real solubility.

Solubilities of $\mathrm{AMB} \cdot \mathrm{HCl}$ and $\mathrm{BMH} \cdot \mathrm{HCl}$ were determined in three solvents: water, ethanol and 1-octanol. Two methods were used: visual-dynamic and spectrophotometric. As a result, six solid-liquid phase diagrams were determined in binary systems $\{$ drug $(1)+$ water, ethanol or 1-octanol (2)\}, where five of them were conducted by the visual-dynamic method and one by the spectrophotometric method. Two examined substances showed opposite character in the chosen solutions. The solubility of $\mathrm{AMB} \cdot \mathrm{HCl}$ was the highest in water and lower in alcohols (ethanol, 1-octanol) and the opposite was found for $\mathrm{BMH} \cdot \mathrm{HCl}$. The experimental points were used to describe phase equilibria using three thermodynamic correlation equations: the Wilson, UNIQUAC and NRTL. The obtained parameters may be helpful in determining the expected solubility of the tested substances in the temperature range higher than those studied experimentally.

The Bates-Schwarzenbach method was used to determine the ionization constants of $\mathrm{AMB} \cdot \mathrm{HCl}$ and $\mathrm{BMH} \cdot \mathrm{HCl}$. The experimental values of ionization constants indicate that they are slightly dissociated and occur mostly in non-ionized form but also the $\mathrm{p} K_{\mathrm{a}}$ values are lower at $298.2 \mathrm{~K}$ than at $310.2 \mathrm{~K}$. These values may be helpful in determining the pharmaceutical doses of active biological substances.

The studies aim to determine the basic physicochemical properties of active pharmaceutical ingredients. They are necessary to assess the suitability of the substance or the possible modification of the structure to achieve the expected properties. The research allows one to assess the thermal stability of the substance, solubility, which affects the determination of the optimal route of administration of the substance, and finally the ionization constant, which have impact on the ability of the substance to be absorbed.

Supplementary Information The online version contains supplementary material available at https://doi. org/10.1007/s10953-021-01068-5.

Acknowledgements Funding for this research was provided by the Warsaw University of Technology, Warsaw, Poland. 
Open Access This article is licensed under a Creative Commons Attribution 4.0 International License, which permits use, sharing, adaptation, distribution and reproduction in any medium or format, as long as you give appropriate credit to the original author(s) and the source, provide a link to the Creative Commons licence, and indicate if changes were made. The images or other third party material in this article are included in the article's Creative Commons licence, unless indicated otherwise in a credit line to the material. If material is not included in the article's Creative Commons licence and your intended use is not permitted by statutory regulation or exceeds the permitted use, you will need to obtain permission directly from the copyright holder. To view a copy of this licence, visit http://creativecommons.org/licenses/by/4.0/.

\section{References}

1. Savjani, K.T., Gajjar, A.K., Savjani, J.K.: Drug solubility: importance and enhancement techniques. ISRN Pharm. 2012, 195727 (2012)

2. Rogers, D.F.: Mucoactive agents for airway mucus hypersecretory diseases. Respir. Care 52(9), 11761193 (2007)

3. Martin, G.P., Loveday, B.E., Marriott, C.: The effect of bromhexine hydrochloride on the viscoelastic properties of mucus from the mini-pig. Eur. Respir. J. 3(4), 392-396 (1990)

4. Yanaura, S., Imamura, N., Miwa, M.: Effects of expectorants on the canine tracheal ciliated cells. Jpn. J. Pharmacol. 31(6), 957-965 (1981)

5. Kack, J., Koss, F.W., Schraven, E. and Beisenherz, G.: US Patent 3,536,713, October 27, 1970, assigned to Boehringer Ingelheim GmbH (ambroxol)

6. Kack, J., Koss, F.W., Schraven, E. and Beisenherz, G.: US Patent 3,336,308, October 27, 1970, assigned to Boehringer Ingelheim $\mathrm{GmbH}$ (bromhexine)

7. Barton, A.F.M.: CRC Handbook of Solubility Parameters and Other Cohesion Parameters. CRC Press, Boca Raton (1985)

8. Domańska, U., Pobudkowska, A., Pelczarska, A., Gierycz, P.: p $K_{\mathrm{a}}$ and solubility of drugs in water, ethanol, and 1-octanol. J. Phys. Chem. B 113(26), 8941-8947 (2009)

9. Pobudkowska, A., Szabłowska, A., Nosol, K.: Physicochemical properties and solubilities of drug's hydrochlorides in water and alcohols. Int. J. Pharm. Res. Rev. 5, 19-32 (2016)

10. Pobudkowska, A., Jurkowska, B.A., Wiatrowski, M.A.: Study of phase equilibria and the physicochemical properties of selected pharmaceuticals. Fluid Phase Equilib. 406, 209-216 (2015)

11. Bates, R.G., Gary, R.: Acidity functions. Values of the quantity $\mathrm{p}\left(\mathrm{a}_{\mathrm{H}} \gamma_{\mathrm{Cl}}\right)$ for buffer solutions from 0 to $95^{\circ}$ C. J. Res. Nat. Bur. Stand. A Phys. Chem. 65A(6), 495-505 (1961)

12. Pobudkowska, A., Domańska, U., Jurkowska, B.A., Dymczuk, K.: Solubility of pharmaceuticals in water and alcohols. Fluid Phase Equilib. 392, 56-64 (2015)

13. Pobudkowska, A., Domańska, U., Kryska, J.A.: The physicochemical properties and solubility of pharmaceuticals - methyl xanthines. J. Chem. Thermodyn. 79, 41-48 (2014)

14. Łukowska-Chojnacka, E., Pobudkowska, A., Bretner, M.: Study of the physicochemical properties of protein kinase CK2 inhibitors-TBBt, TBBi and 2-Me-TBBi. Fluid Phase Equilib. 479, 52-62 (2019)

15. Domańska, U., Pobudkowska, A., Pelczarska, A.: Solubility of sparingly soluble drug derivatives of anthranilia acid. J. Phys. Chem. B 115, 2547-2554 (2011)

16. Wilson, G.M.: Vapour-liquid equilibrium. XI. A new expression for the excess free energy of mixing. J. Am. Chem. Soc. 86, 127-130 (1964)

17. Renon, H., Praustnitz, J.M.: Local composition in thermodynamics excess functions for liquid mixtures. AIChE J. 14, 135-144 (1968)

18. Abrams, D.S., Prautnitz, J.M.: Statistical thermodynamics of liquid mixtures: a new expression for the excess Gibbs energy of partly or complete miscible systems. AIChE J. 21, 116-128 (1975)

19. Domańska, U., Królikowska, M.: Density and viscosity of binary mixtures of thiocyanate ionic liquids + water as a function of temperature. J. Solution Chem. 41(8), 1422-1445 (2012)

20. Design Institute for Physical Properties, Sponsored by AIChE. DIPPR Project $801-$ Full Version. This Knovelized 2016 Edition of DIPPR 801. [Online] update 2006-2016-12-01. http://www.knovel.com/ web/portal/browse/display

21. Riddick, J.A., Bunger, W.B., Sakano, T.K.: Physical Properties and Methods of Purification. Organic Solvents, 4th edn. Wiley-Interscience, New York (1986)

22. The DrugBank database, https://www.drugbank.ca/salts/DBSALT000563 (access: 06.03.20)

23. The DrugBank database, https://www.drugbank.ca/salts/DBSALT001092. Accessed 3 June 2020

24. ChemicalBook database, https://www.chemicalbook.com/ChemicalProductProperty_US_CB4304139. aspx. Accessed 3 June 2020 
25. ChemicalBook database, https://www.chemicalbook.com/ChemicalProductProperty_US_CB3249453. aspx. Accessed 3 June 2020

Publisher's Note Springer Nature remains neutral with regard to jurisdictional claims in published maps and institutional affiliations. 